\title{
Etiology and pathogenicity of two different isolates of Colletotrichum spp. obtained from physic nut seeds ${ }^{1}$
}

\author{
Gil Rodrigues dos Santos ${ }^{2 *}$, Hugo José Tozze Júnior³, Danila Alves Corrêa de Sá2, \\ Gleiber Quintão Furtado ${ }^{4}$, Nelson Sidnei Massola Júnior ${ }^{3}$
}

\begin{abstract}
The species known as physic nut (Jatropha curcas L.) has become important as one of main sources of feedstock for biodiesel production. The aims of this study were characterizing two different isolates of Colletotrichum spp. obtained from seeds of this species, through morphological, cultural, and molecular analyses; as well as assessing pathogenicity of both isolates on leaves and fruit of this plant species. For morphological analysis, length and width of 30 spores of each isolate, produced on medium Malt Extract-Agar (MEA), at $25 \pm 1{ }^{\circ} \mathrm{C}$, and under constant light, were measured. Cultural analysis was performed by the fungus growth on PDA medium, through daily measurements of the mycelial growth, and the color of colonies after seven days incubation. DNA of the isolates was extracted and specific oligonucleotides primers (region ITS4) were identified by PCR and used to identify C. capsici (CcInt) and C. gloeosporioides (CgInt). Pathogenicity of isolates was assessed on plants aged 10,20,30, 40, 50, and 60 days after sowing and fruits at six maturation stages. Based on these analyses, isolates were identified as $C$. gloeosporioides and C. capsici. Young plants and the older fruits were more susceptible to infection by the two fungus species.
\end{abstract}

Index terms: anthracnose, Jatropha curcas, C. capsici, C. gloeosporioides.

\section{Etiologia e patogenicidade de dois diferentes isolados de Colletotrichum spp. obtidos de sementes de pinhão manso}

\begin{abstract}
RESUMO - A espécie pinhão manso (Jatropha curcas L.), vem se destacando como a principal matéria-prima para produção de biodiesel. O objetivo deste estudo foi caracterizar dois isolados de Colletotrichum spp., obtidos de sementes dessa espécie, através de análise morfológica, cultural e molecular, além de avaliar a patogenicidade desses isolados em folhas e frutos da planta. Para análise morfológica foram medidos o comprimento e a largura de 30 esporos de cada isolado, produzidos em meio de cultura Extrato de Malte-Agar, a $25 \pm 1{ }^{\circ} \mathrm{C}$, sob luz contínua. A análise cultural foi realizada pelo crescimento do fungo em meio de BDA, com avaliações diárias do crescimento do micélio e pela coloração da colônia, após sete dias de incubação. O DNA dos isolados foi extraído e oligonucleotídeos específicos (região ITS4) foram identificados pela técnica de PCR e utilizados para identificar C. capsici (CcInt) e C. gloeosporioides (CgInt). A patogenicidade dos isolados foi avaliada em plantas com diferentes idades (10, 20,30, 40, 50 e 60 dias após semeadura) e em frutos em seis estádios de maturação. Com base nestas análises os isolados foram identificados como C. capsici e C. gloeosporioides. Plantas jovens e frutos desenvolvidos foram mais suscetíveis à infecção pelas duas espécies do fungo.
\end{abstract}

Termos para indexação: antracnose, Jatropha curcas, C. capsici, C. gloeosporioides.

\section{Introduction}

The species Jatropha curcas L., commonly known as physic nut, is a shrub native to tropical America, belonging to the family Euphorbiaceae. Currently, the seeds of this plant, which may contain until $37.5 \%$ of oil, have gained prominence as a major source of feedstock for production of Biodiesel. Besides, the plant can also be used for: erosion control; recovery of degraded areas, medicinal uses, honey production, formation of windbreaks, and manufacture of cosmetics, among other
${ }^{1}$ Submitted on $02 / 16 / 2012$. Accepted for publication on 10/23/2012. ${ }^{2}$ Departamento de Fitopatologia, Universidade Federal do Tocantins, 77402-970, Gurupi, TO, Brasil.

${ }^{3}$ Departamento de Fitopatologia e Nematologia, Universidade de São Paulo, 13418-900 - Piracicaba, SP, Brasil.
${ }^{4}$ Departamento de Fitopatologia, Universidade Federal de Viçosa, 36570-000 Viçosa, MG, Brasil.

*Corresponding author < gilrsan@uft.edu.br> 
uses (Openshaw, 2000; Kumar and Sharma, 2008).

Despite being considered a species resistant to diseases and pests, various diseases caused by fungi have already been detected in plants of this crop, among them rusts, powdery mildew, root rot, anthracnose, and ash dieback disease, besides viruses (Raj et al., 2008; Franco and Gabriel, 2008; Pereira et al., 2009).

However, among the fungi that can cause damage to that crop, the genus Colletotrichum and its teleomorph Glomerella contains species considered important pathogens of plants of various cereals, horticultural plants, ornamentals, and fruit trees in tropical, subtropical and temperate regions worldwide (Bailey and Jegger, 1992). Although information on diseases caused by Colletotrichum spp. in physic nut are scarce, Franco and Gabriel (2008) have reported that C. gloeosporioides and $C$. capsici are causal agents of disease on leaves and fruits of this plant species. For a long time, the species $C$. gloeosporioides was characterized based on morphological characteristics (Sutton, 1992) and also by analysis of ITS region of ribosomal DNA (Mills et al., 1992). Nevertheless, more recent studies of molecular biology, based on other genomic regions, have shown that $C$. gloeosporioides, in fact is a complex of species (Cai et al., 2009; Hyde et al., 2009; Damm et al., 2010).

There is not much information about the pathogens that can be transmitted by seeds of physic nut. Considering that this is one of the main ways of disseminating pathogens, which may cause serious damage to the crop, it is important to investigate the etiology and pathogenicity of microorganisms associated to seeds of this species, so that more efficient measures can be taken to their control. Based on the foregoing, the aims of this study were characterizing and identifying two different isolates of Colletotrichum spp. detected in seeds of physic nut, by means of morphological, cultural and molecular characteristics; as well as assessing pathogenicity of these two isolates on leaves and fruits of this oilseed.

\section{Material and Methods}

\section{Characterization of the Colletotrichum spp. isolates}

The experiments were carried out at the Laboratory of Plant Pathology of the Federal University of Tocantins, state of Tocantins (UFT-TO), Northern Brazil, and Laboratory of Pathogenic Fungi of the University of São Paulo - College of Agriculture "Luiz de Queiroz" (USP- ESALQ) State of São Paulo, Southeast Brazil.

The isolates of Colletotrichum spp. analyzed in this study were obtained in tests conducted by the method of filter paper (blotter-test), while conducting a survey of the main pathogenic fungi associated to physic nut seeds (Sá et al., 2011). Among the fungi present in the seeds analyzed were detected two isolates of Colletotrichum spp. with distinct morphologies. These isolates were designated P-01 and P-02. The first isolate has presented conidia falcate with tapered apices, and the second isolate has presented conidia straight, oblongs and with rounded apices. For identification, both isolates were analyzed by the morphological characteristics of the conidia and by cultural analyses, as well as molecular analyses using conventional PCR, as following described:

The cultural analysis was performed by using discs of mycelium (6 mm diameter), cut with the aid of a sterile cork borer, from the extremities of the growth zone of the fungus mycelium grown upon PDA culture medium (Difco ${ }^{\circledR} ; 39$ g .L L $^{-1}$ water) during seven days, at $25 \pm 1{ }^{\circ} \mathrm{C}$, with photoperiod of $12 / 12 \mathrm{~h}(\mathrm{~L} / \mathrm{D})$. These discs were then immediately transferred to the center of Petri dishes containing identical PDA culture medium and incubated also at a temperature of $25 \pm 1{ }^{\circ} \mathrm{C}$, and photoperiod of 12/12 h (L/D) under fluorescent light. Fungal growth was assessed during seven days, through daily assessments of the perpendicular diameters of the colonies; what was performed with aid of a ruler graduated in millimeters. On the seventh day of incubation, the color of each colony was also evaluated. The experiment was conducted in a completely randomized experimental design, with twelve repetitions for each isolate of the fungus. Each replication consisted of one single Petri dish; this way, totaling 12 plates for each isolate assessed.

On analysis for detecting possible morphological differences between the two isolates, 30 conidia of each isolate were collected in colonies of the fungus, grown on culture media Malt Extract-Agar (MEA) (Malt extract $20 \mathrm{~g}$ + Peptone $1 \mathrm{~g}+$ Dextrose $20 \mathrm{~g}+$ Agar $15 \mathrm{~g}+$ Distilled water $1 \mathrm{~L}=$ total volume), at $25 \pm 1{ }^{\circ} \mathrm{C}$, under constant light. Then, these conidia were examined under a microscope (Brand Zeiss, model Axioskop 2) equipped with image capture system (Axiocam) and an image analysis software (Axiovision). During this procedure the predominant form of the conidia was characterized; and concomitantly was measured the length and diameter of conidia produced.

For molecular typing, DNA extraction was performed according to the method described by Dellaporta et al. (1983). To this, it was performed the detection of a fragment of 460 base pairs corresponding to the genomic fragment within the region ITS4 with a combination of primers: CgInt (5'GGCCTCCCGCCTCCGGGCGG3'), specific for C. gloeosporioides; CaInt2 (5'GGGGAAGCCTCTCGCGG3'), specific for $C$. 
acutatum, and CcInt (5'TCTCCCCGTCCGCGGGTGG3'), specific for $C$. capsici, with the primer ITS4 (5'TCCTCCGCTTATTGATATGC3').

Each reaction was performed separately with $25 \mu \mathrm{L}$ of a solution containing buffer $1 \mathrm{X}(50 \mathrm{mM} \mathrm{KCl}, 10 \mathrm{mM}$ Tris $\mathrm{HCl})$, 60 ng DNA, $1.5 \mathrm{mM} \mathrm{MgCl} 2,0.2 \mathrm{mM}$ of each dNTP, $0.5 \mathrm{mM}$ each of primers, and 1.25 U Taq DNA polymerase (all reagents were from Invitrogen ${ }^{\circledR}$ Brand). PCR reactions for detection of C. acutatum and C. gloeosporioides were conducted in 35 cycles of 30 seconds at $94{ }^{\circ} \mathrm{C}, 45$ seconds at $60{ }^{\circ} \mathrm{C}$, and 90 seconds at $72{ }^{\circ} \mathrm{C}$; and PCR reactions for identification of $C$. capsici were conducted in 35 cycles of 30 seconds at $94{ }^{\circ} \mathrm{C}$, 30 seconds at $63{ }^{\circ} \mathrm{C}$ and 90 seconds at $72{ }^{\circ} \mathrm{C}$. For all reactions as control it were used DNA from the isolate Col-19 ( $C$. acutatum), isolate Col-44 (C. capsici), and isolate Col-48 (C. gloeosporioides) preserved in the Fungi Culture Collection, of the Mycology Laboratory of ESALQ/USP. Each amplification reaction was repeated two times for each isolate.

After amplification, the PCR products were applied to $1 \%$ agarose gel and stained with SYBR-SAFE ${ }^{\circledR}$. The electrophoretic run was performed at constant current of 5 volts. $\mathrm{cm}^{-1}$, for $1 \mathrm{~h}$. The gels were visualized on a UV transilluminator and photographed using the Eagle Eye apparatus (Stratagene co., La Jolla, CA, USA).

\section{Pathogenicity tests}

The pathogenicity assessment of the isolates $\mathrm{P}-01$ and P-02 was performed on physic nut leaves, as well as on fruits of this species at six distinct development stages. For obtaining physic nut plants aged 10,20,30,40,50, and 60 days after seeding (DAS), at each interval of 10 days, seeds were placed to germinate in pots (three plants per pot) with capacity of 4 L each, containing sterilized substrate type Plantmax ${ }^{\circledR}$, with addition of $6 \mathrm{~g}$ urea. For superficial disinfection, the seeds were immersed in a $70 \%$ alcohol solution, for $30 \mathrm{sec}$. and then in a sodium hypochlorite solution $2 \%$, for $2 \mathrm{~min}$., and immediately after were washed in sterile distilled water for $1 \mathrm{~min}$. For inoculating both the isolates, a suspension of conidia was prepared at a concentration of $1 \times 10^{6}$ conidia. $\mathrm{mL}^{-1}$, which was adjusted with aid of a Neubauer Counting chamber. Subsequently, the surface adaxial (upper) and abaxial (lower) of all leaves in each plant were inoculated with this suspension with aid a manually operated sprayer, until reaching maximum retention point of the suspension on the leaves. The inoculated plants were then placed in a moist chamber, at a temperature of $25^{\circ} \mathrm{C}$ and continuous dark, for a period of $72 \mathrm{~h}$. After this incubation period, the plants were kept in a greenhouse until the assessment moment, which was performed at 7 days after inoculating, as much for incidence as for disease severity.

For obtaining data relating to disease incidence it was considered the percentage of leaves presenting disease symptom as compared to total number of leaves of each plant. Disease severity was assessed using a grading scale proposed by Santos et al. (2009) where: 0 (healthy plant), 1 (less than $1 \%$ diseased leaf area), 3 ( $1 \%$ to $5 \%$ diseased leaf area), 5 ( $6 \%$ to $25 \%$ diseased leaf area), 7 ( $26 \%$ to $50 \%$ diseased leaf area), and 9 (more than $50 \%$ diseased leaf area).

A completely randomized experimental design was used with three replicates for each treatment, which were arranged in a $6 \times 2$ factorial [6 stages of plant development $(10,20$, 30, 40, 50 and 60 DAS) x 2 isolates of Colletotrichum spp. (P-01 and P-02)]. Each replication consisted of three plants grown in the same pot. As control, three plants were sprayed only with sterile water to each developmental stage. The experiment was conducted for two times.

The pathogenicity test was performed on fruits at five different maturation stages: 1 - Green fruits, with $1 \mathrm{~cm}$ in diameter; 2 - Green fruits and with $1.5 \mathrm{~cm}$ in diameter; 3 - Green fruits and with $2 \mathrm{~cm}$ in diameter; 4 - fruits green-yellowish and with $2.5 \mathrm{~cm}$ in diameter; and 5 - yellow fruits and with a diameter $\geq 2.5 \mathrm{~cm}$.

Before inoculation, fruits were surface-disinfected with a solution of sodium hypochlorite $1 \%$, rinsed with sterile distilled water and placed within acrylic germination boxes $\left(G^{2} r_{b o x}{ }^{\circledR}\right)$, upon two sheets of sterile filter paper moistened with sterile distilled water containing $100 \mathrm{ppm}$ streptomycin sulfate. Subsequently, four superficial lesions were made in each fruit with a sterile needle and on each of these lesions was deposited a mycelium disc of the fungus with $5 \mathrm{~mm}$ diameter. The Gerbox ${ }^{\circledR}$ containing the inoculated fruits was then kept in an incubation chamber, at $25^{\circ} \mathrm{C}$ and photoperiod of $12 / 12 \mathrm{~h}$, for seven days.

Disease severity was evaluated by the presence or absence of typical symptoms on the inoculated fruits, as well as by size of lesion caused by the fungus, which was obtained by using a ruler graduated $(\mathrm{cm})$ to measure the diameter of the lesions formed on fruit surface. From the total diameter of lesion it was excluded the disc diameter of mycelium used for inoculation. For confirmation of causal agent, the fungus was recovered from these lesions, and then grown singly in pure culture until new sporulation on PDA culture medium. After sporulation, microscopy slides were prepared with mycelium and conidia of the fungus for visualization and identification of the causal agent under optical microscope, thus fulfilling Koch's postulates.

For this experiment, it was used a completely randomized experimental design with 10 replications, with treatments 
arranged in a factorial $5 \times 2$ (5 stages of fruit maturation $\times 2$ isolates of the fungus Colletotrichum spp.). Each replication included two fruits for each maturation stage. The control included two wounded fruits, for each maturation stage, but without inoculation. The experiment was performed twice with an interval of 30 days.

Results presented for both pathogenicity tests refer to the mean of results obtained for the two experiments, once there was homogeneity of variances by Bartlett's test (Gomez and Gomez, 1984). Data were subjected to regression analysis and adjustments were performed to values obtained from the coefficients of determination using the statistical program SISVAR (Ferreira, 2003).

\section{Results and Discussion}

\section{Characterization of the fungus Colletotrichum spp. isolates}

The isolate P-01 has formed colonies with the coloration of mycelium ranging from white to gray, and with sporulation of orange coloration, with presence of setae and with mean speed of growth of $6.6 \mathrm{~mm}^{-d_{a y}{ }^{-1}}$ and conidia falcate with tapered apices; and dimension means of $23.6 \mu \mathrm{m}$ in length and $2.3 \mu \mathrm{m}$ in width (Figure 1E).

The isolated P-02 has also formed colonies with color of mycelium ranging from white to light-gray with orange sporulation and presence of setae; however, with a growth rate of $11.6 \mathrm{~mm}$.day ${ }^{-1}$ and conidia oblong with rounded apices, and length and width of 14.5 and $4.4 \mu \mathrm{m}$, respectively (Figure 1F).

Based on descriptions reported by Sutton (1992) for species of Colletotrichum spp., the isolate P-01 belongs to species $C$. capsici (Syd. \& P. Syd.) E. J. Butler \& Bisbye; and the isolate P-02 may be placed among species of the complex C. gloeosporioides (Penz.) Sacc.

Regarding to mycelial growth, the isolated P-02 ( $C$. gloeosporioides) has presented a mycelium mean growth $\left(11.6 \mathrm{~mm}\right.$ day $\left.^{-1}\right)$ higher than that observed for the isolated P-01 (C. capsici), which was 6.6 mm.day ${ }^{-1}$. Therefore, this parameter was very helpful in differentiating between the two species.

Results achieved by the PCR analyses have confirmed the distinction obtained by the morph-cultural characteristics (Figure 2). The isolate P-01 and the standard to $C$. capsici (Col-44) have had DNA fragments (460 bp) amplified only when were used the CcInt/ITS4 primers, which identify the species C. capsici (Figure 2A); while the isolated P-02 as well as the standard to $C$. gloeosporioides (Col-48) have had DNA fragments (450 bp) amplified only by the primers CgInt/ITS4, which are specific for the complex $C$. gloeosporioides (Figure 2B).

However, there are still needed further and more detailed studies involving more precise molecular methods, such as phylogenetic analysis based on sequencing of specific regions of genome (Cai et al., 2009), which may identify definitively the species into which the isolate P-02 can be placed in the complex of species of the C. gloeosporioides group.
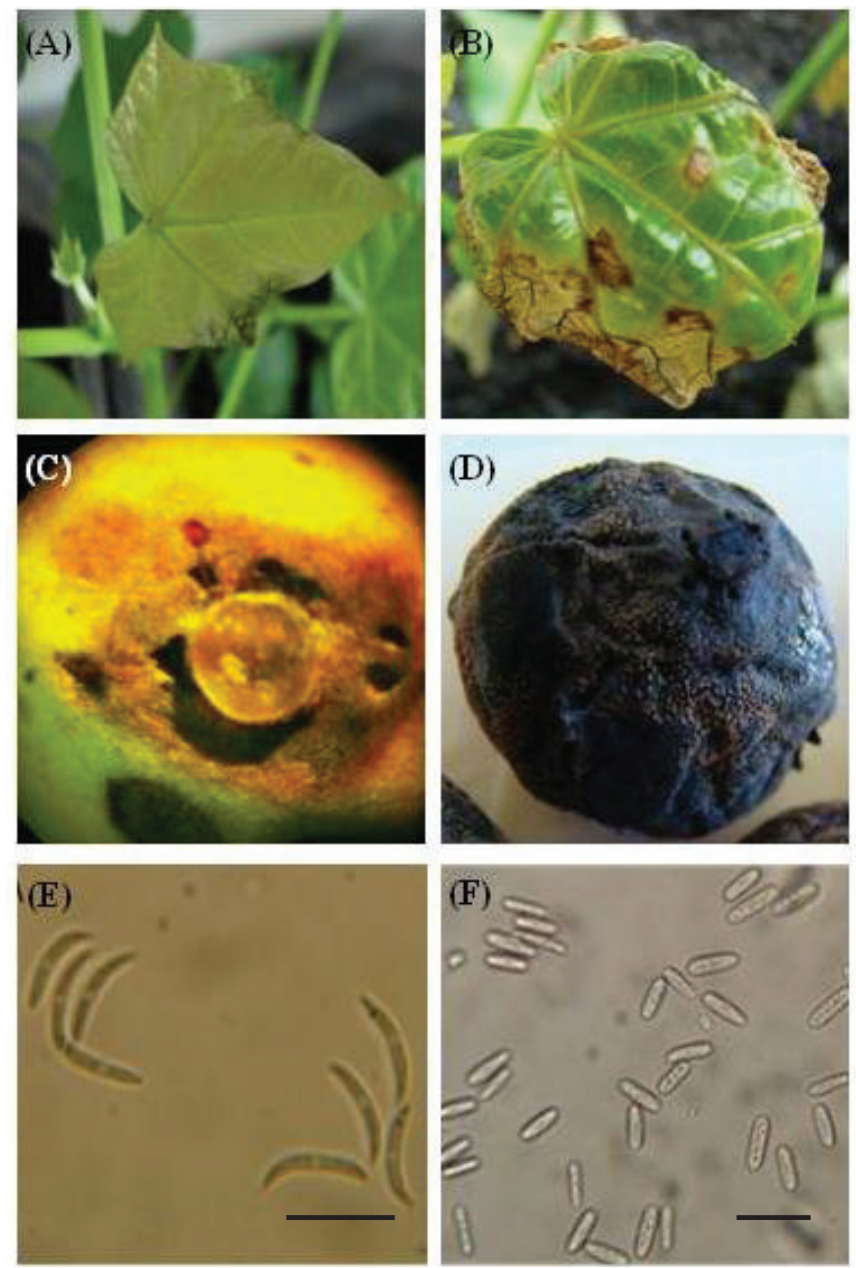

Figure 1. Photographic illustration of the symptoms of anthracnose caused through infection by two isolates of Colletotrichum spp. on leaves and fruit of physic nut; and morphology of the conidia of both the isolates. (A) initial symptoms on leaves; (B) advanced symptoms on leaves; (C) development of initial symptom on fruit starting from the inoculation site; (D) fruit completely necrotic and covered by the orange sporulation of the pathogen; and (E) conidia of isolate P-01 (C. capsici), (F) conidia of the isolated P-02 (C. gloeosporioides). $\mathrm{Bar}=20 \mu$. 

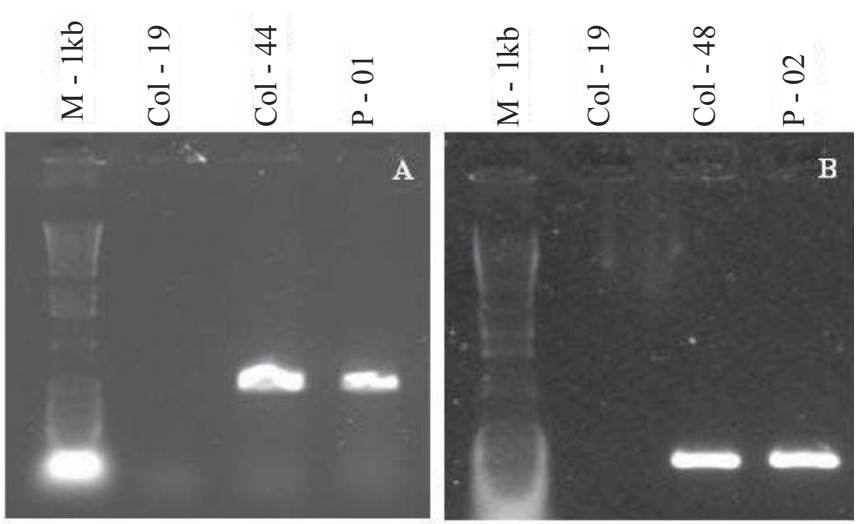

Figure 2. Pattern of fragments amplified by PCR using the primers CcInt/ITS4, specific for Colletotrichum capsici (A) and CgInt/ITS4, specific for the complex Colletotrichum gloeosporioides (B); observed in $1 \%$ agarose gel and stained with SYBR-SAFE ${ }^{\circledR}$. Subtitles: $M(1 \mathrm{~Kb}$ molecular marker; brand Invotrogen $^{\circledR}$ ); P-01 and P-02 (isolates originating from seeds of physic nut); Col-44, Col-19, and Col-48 = standard for Colletotrichum capsici, Colletotrichum acutatum, and Colletotrichum gloeosporioides, respectively.

Pathogenicity testes

The two isolates have caused similar symptoms when inoculated on leaves of physic nut. The first symptoms were observed three days after inoculation (DAI) in the form of small and translucent lesions (anasarca), randomly distributed throughout the leaf blade, and darkening of veins of the plant leaves (Figure 1A). Later, the lesions became larger, with dark-brown coloration and irregular shape (Figure 1B), and around five DAI, it has occurred defoliation.

A

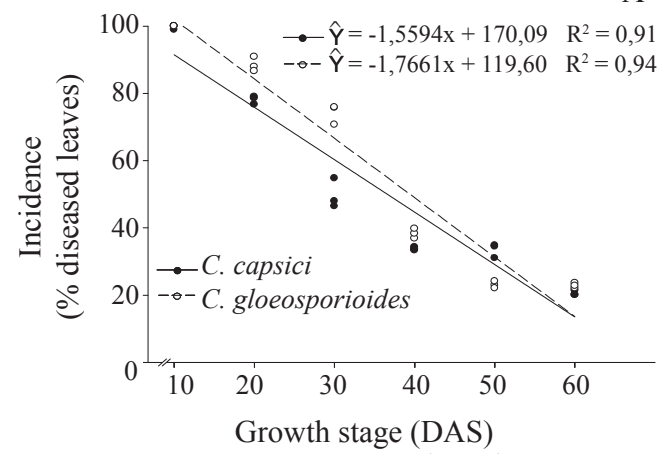

It was also observed that only the youngest leaves were susceptible to both isolates. Plants inoculated with the isolated P-01 (C. capsici) have presented $99.6 \%$ of disease incidence on the leaves inoculated at 10 DAS, while plants inoculated with isolate $\mathrm{P}-02$ (C. gloeosporioides) have shown $100 \%$ of leaves with the symptoms of disease (Figure $3 \mathrm{~A}$ ). The fact that there was superiority of older leaves on the more developed plants, at inoculation moment, explains the cause of the lower indixes of disease incidence on the plants with 60 DAS (Figure 3A). The same linear negative behavior was observed for the disease severity (Figure 3B); thus confirming the lowering in susceptibility to the pathogen when plants become older. Within this context, Smith et al. (1990) observed that for strawberry (Fragaria x ananassa Duch.) crop seedlings aged two to four weeks were more susceptible to fungus Colletotrichum fragariae after transplantation than seedlings aged between 14 to 18 weeks.

In relation to the lower susceptibility of older tissues, Hong et al. (2001) in studies on resistance of cowpea (Vigna unguiculata L.) to the fungus Colletotrichum coccodes have observed that plants of this species, when inoculated at the stage of two leaves, have had a rapid and massive colonization by the pathogen in all tissues of plant, including the vascular tissue, with collapse of cytoplasm, chloroplasts distortion, and rupture of cell walls of infected host; which resulted in progressive lesions of type anasarca (translucent). In addition to these results, the same authors have also found other different responses to the resistance to colonization by the fungus $C$. coccodes in the older plants, including the presence of amorphous material in xylem vessels, fibrillar material in the intercellular space, and protein aggregates in the vacuole; which may imply in the expression of proteins related to plant defense, such as chitinase and $\beta-1,3-$ glucanase (Mauch and Staehelin, 1989).

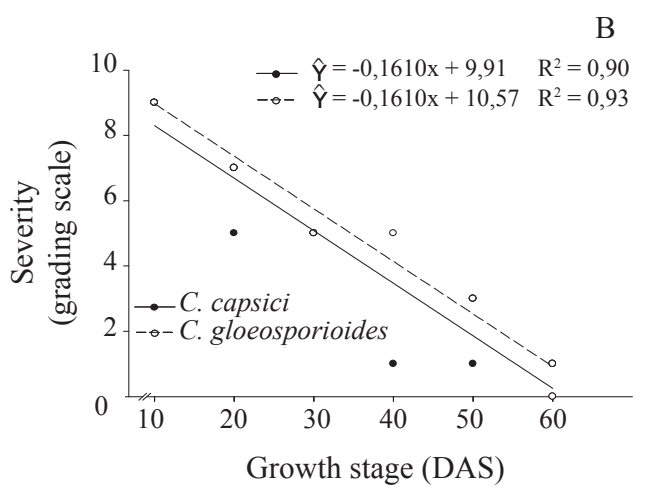

Figure 3. Incidence (A) and severity (B) of the anthracnose disease on physic nut seedlings, caused by Colletotrichum capsici and $C$. gloeosporioides, inoculated with conidia suspension $\left(1 \times 10^{6}\right.$ conidia. $\left.\mathrm{mL}^{-1}\right)$ at different seedling growth stages. DAS $=$ days after sowing; grading scale: 0 (healthy plant), 1 (less than $1 \%$ diseased leaf area), 3 ( $1 \%$ to $5 \%$ diseased leaf area), 5 (6\% to $25 \%$ diseased leaf area), 7 (26\% to 50\% diseased leaf area), and 9 (more than 50\% diseased leaf area). 
However, greater susceptibility of younger tissue has also already been observed in the pathosystems tobacco/blue mold (Nicotiana tabacum L. x Peronospora tabacina D.B. Adam) (Reuveni et al., 1986), lettuce/downy mildew (Lactuca sativa L. x Bremia lactucae Regel) (Dickinson and Crute, 1974), and cowpea/ anthracnose (Vigna unguiculata (L.) Walp. x Colletotrichum capsici (Syd.) E.J. Butler \& Bisby) (Pring et al., 1995).

Isolates P-01 and P-02 were also pathogenic to the fruits of physic nut (Figure 1C and 1D); but with no visible difference between the symptoms caused by both isolates. The lesions caused by both isolates have presented a depressed aspect, and mummification of fruits has occurred with the evolution of symptoms (especially in the older fruits). At this stage it was possible detecting more clearly the signs of the disease and the intense sporulation of the pathogen upon the lesions, which have shown an orange coloration (Figure 1D).

Regarding susceptibility of the fruits inoculated in different maturation stages, it can be observed that there was a positive correlation between factors age $\mathrm{x}$ susceptibility of the fruit, i.e., the higher the age of fruit, the greater was the diameter of lesions caused by the two isolates of the fungus on these fruits (Figure 4).

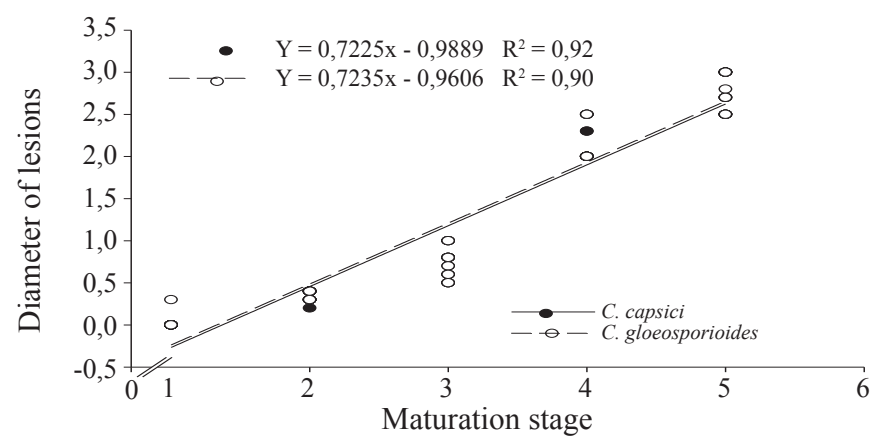

Figure 4. Development of the anthracnose disease caused by Colletotrichum capsici and Colletotrichum gloeosporioides as a function of maturation stages of the physic nut fruits. Maturation stages: 1 - green fruit, with $1 \mathrm{~cm}$ in diameter; 2 - green fruit, with 1.5 $\mathrm{cm}$ in diameter; 3 - green fruit, with $2 \mathrm{~cm}$ in diameter; 4 - fruit green-yellowy and with $2.5 \mathrm{~cm}$ diameter; and 5 - yellow fruits and with diameter $\geq 2.5 \mathrm{~cm}$.

The higher susceptibility of fruits at more advanced physiological development stages has already been demonstrated in various hosts $\mathrm{x}$ pathogens interactions such as: strawberry (Fragaria x ananassa Duch.). x Colletotrichum acutatum and C. fragariae (Tanaka et al., 1994); avocado (Persea americana Mill.) x C. gloeosporioides (Prusky and Keen, 1993; Prusky, 1996;); olive tree (Olea europaea L.) x
C. acutatum (Moral et al., 2008); and banana (Musa spp.) x C. musae (Chillet et al., 2007).

Among the mechanisms used to explain the higher resistance of immature fruit to fungi of genus Colletotrichum spp. are included: 1 - lack of the nutrients necessary to the pathogen, but which become available with maturation; 2 - the presence of compounds antifungal or toxic to the pathogen, whose concentration decreases with fruit ripening; and 3 anatomical changes resulting from maturation, as reduction on cuticle thickness (Prusky and Keen, 1993; Prusky, 1996; Moral et al., 2008). For example, in the interaction between C. gloeosporioides $\mathrm{x}$ avocado in the development of anthracnose disease, high concentrations of dienes which are antifungal preformed compounds and that are present in immature avocado fruit pericarp promote the quiescence of infection by the fungus, after formation of the appressoria, causing the infection process continues only after the ripening of fruit; what explains the higher resistance of the unripe avocado fruits to anthracnose (Binyamini and SchiffmannNadel, 1972; Pegg et al., 2002).

Results obtained within this study may become useful in defining the best period to carry out chemical control, in case this strategy is adopted in the future by producers. These results show that the chemical control should be applied in the period of intense vegetative growth, as well as in the beginning of maturation of fruits. Nevertheless, the occurrence of quiescent infections in unripe physic nut fruits should be better investigated, since this phenomenon may occur in the most pathosystems involving tropical plants and various species within the genus Colletotrichum spp.; what turns the anthracnose disease one the most important postharvest diseases (Lopez, 2001).

In a study involving the fungi $C$. capsici and $C$. gloeosporioides, Sá et al. (2011) have studied as much the transmissibility of fungus from fruit to seeds as from seeds to seedlings of physic nut, and have found that $100 \%$ transmission occurs from fruit to seeds, and that transmissibility of fungus from seed to seedlings is nil. According to these same authors this deficiency on transmission is probably due to the fast release of the seed coat during germination process, as well as due to the fact that these fungi were detected only externally on the physic nut seeds. Therefore, the tegument appears to function as a natural barrier preventing their infection by these pathogenic agents. Although it has not been observed any transmission of the fungus from seed to seedlings, the presence of structures of propagation of the fungus (hyphae and conidia) associated with the teguments released during the germination process can be an important source of initial inoculum and favor the occurrence of infections in the tender 
tissues of the physic nut seedlings. This manner, removal of the seed coats released onto the substrate may be an important measure of the disease control on young plants.

Thus, for a better understanding of interactions that occur between different isolates of Colletotrichum spp. and physic nut plants (leaves, fruits and seeds), further studies are needed in order to obtain a better knowledge of the incidence, distribution, and pathogenicity of the fungus species associated to this oilseed.

\section{Conclusions}

By morphological and molecular characteristics, the two isolates of Colletotrichum spp. belong to the species Colletotrichum capsici and Colletotrichum gloeosporioides;

Leaves and fruits of physic nut are susceptible to anthracnose caused by the species Colletotrichum capsici and Colletotrichum gloeosporioides;

Younger plants and older fruits of physic nut are more susceptible to anthracnose caused by Colletotrichum capsici and Colletotrichum gloeosporioides;

The species Colletotrichum capsici and Colletotrichum gloeosporioides cause similar symptoms on leaves and fruit of physic nut.

\section{Acknowledgments}

To CNPq for granting the award of Research Productivity to the first and the fifth author, and by the scholarship granted for achievement of the MS degree of the third author. To FAPESP (Proc. 2011/11629-1) for the financial support provided to that part of the research developed at ESALQ/USP.

\section{References}

AVRDC. 2004. Evaluation of phenotypic and molecular criteria for the identification of Colletotrichum species causing pepper anthracnose in Taiwan. Progress Report, 2003. Shanhua: AVRDC. http://www.avrdc.org/ pdf/pr2003.pdf. Accessed on: $01^{\text {st }}$ May 2011.

BAILEY, L.A; JEGGER, M.J. Colletotrichum: Biology, Pathology and control. Ed. Wallingford: CAB International, 1992. 388p

BINYAMINI, N.; SCHIFFMANN-NADEL, M. Latent infection in avocado fruit due to Colletotrichum gloeosporioides. Phytopathology, v.62, p.592-594, 1972.

CAI, L.; HYDE, K.D.; TAYLOR, P.W.J.; WEIR, B.S.; WALLER, J.; ABANG, M.M.; ZHANG, J.Z.; YANG, Y.L.; PHOULIVONG, S.; LIU, Z.Y.; PRIHASTUTI, H.; SHIVAS, R.G.; MCKENZIE, E.H.C.; JOHNSTON, P.R. A polyphasic approach for studying Colletotrichum. Fungal Diversity, v.39, p.183-204, 2009. http://www.fungaldiversity.org/fdp/sfdp/fd39-8.pdf

CHILlET, M.; HUBERT, O; DE BELLAIRE, L.L. Relationship between physiological age, ripening and susceptibility of banana to wound anthracnose. Crop Protection, v.26, n.7, p.1078-1082, 2007. http://www sciencedirect.com/science/article/pii/s0261219406002894

DAMM, U.; BARONCELLI, R.; CAI, L.; KUBO, Y.; O'CONNELL, R.; WEIR, B.; YOSHINO, K.; CANNON, P. F. Colletotrichum: species, ecology and interactions. IMA FUNGUS, v.1, n.2, p. 161-165, 2010. http://www. imafungus.org/Issue/2/19.pdf

DELLAPORTA, S.L; WOOD, J.; HICKS, J.B. A plant DNA mini-preparation: version II. Plant Molecular Biology Reporter, v.1, n.4, p.19-21, 1983. http:// www.springerlink.com/content/g028p2457t792qn4/

DICKINSON, C.H.; CRUTE, J.R. The influence of seedling age and development on the infection of lettuce by Bremia lactucae. Annual Applied of Biology, v.76, n.1, p.49-61, 1974. HTTP://ONLINELIBRARY.WILEY COM/DOI/10.1111/J.1744-7348.1974.TB01356.X/ABSTRACT

FERREIRA, D.F; SISVAR: Sistema de análise de variância. Versão 4.6 Lavras: UFLA/DEX, 2003

FRANCO, D.A.S.; GABRIEL, D. Aspectos fitossanitários na cultura do pinhão manso (Jatropha curcas L.) para produção de biodiesel. Biológico, v.70, n.2, p.63-64, 2008.

GOMEZ, K.A.; GOMEZ, A.A. Statistical procedures for agricultural research. 2ed. New York: John Wiley, 1984. 680P.

HONG, J.K.; LEE, Y.K.; JEUN, Y.C.; HWANG, B.K. Histological and ultrastructural study of susceptible and age-related resistance responses of pepper leaves to Colletotrichum coccodes infection. The Plant Pathology Journal, v.17, p.128-140, 2001

HYDE, K.D.; CAI, L.; CANNON, P.F.; CROUCH, J.A.; CROUS, P.W.; DAMM, U.; GOODWIN, P.H.; CHEN, H.; JOHNSTON, P.R.; JONES, E.B.G.; LIU, Z.Y.; MCKENZIE, E.H.C.; MORIWAKI, J.; NOIREUNG, P.; PENNYCOOK, S.R.; PFENNING, L.H.; PRIHASTUTI, H.; SATO, T.; SHIVAS, R.G.; TAN, Y.P.; TAYLOS, P.W.J.; WEIR, B.S.; YANG, Y.L.; ZHANG, J.Z. Colletotrichum - names in current use. Fungal Diversity, v. 39, p. 147-182, 2009. http://www.fungaldiversity.org/fdp/sfdp/fd39-7.pdf

KUMAR, A.; SHARMA, S. An evaluation of multipurpose oil seed crop for industrial uses (Jatropha curcas L.): A review. Industrial Crops and Products, v.28, p.1-10, 2008. http://www.sciencedirect.com/science/article/ pii/s0926669008000046

LOPEZ, A.M.Q. Taxonomia, patogênese e controle de espécies do gênero Colletotrichum. Revisão anual de patologia de plantas, v.9, p.291-337, 2001.

MAUCH, F.; STAEHELIN, L.A. Functional implications of the subcellular localization of ethylene-induced chitinase and $\beta$-1,3-glucanase in bean leaves. The Plant Cell, v.1, p.447-457, 1989. http://www.ncbi.nlm.nih.gov/ pmc/articles/pmc159776/pdf/010447.pdf

MILLS, P.R.; SREENIVASAPRASAD, S.; BROWN, A.E. Detection and differentiation of Colletotrichum gloeosporioides isolates using PCR. FEMS Microbiology Letters, v.98, p.137-144, 1992.

MORAL, J.; BOUHMIDI, K.; TRAPERO, A. Influence of fruit maturity, cultivar susceptibility, and inoculation method on infection of olive fruit by Colletotrichum acutatum. Plant Disease, v.92, n.10, p.1421-1426, 2008. http://apsjournals.apsnet.org/doi/pdfplus/10.1094/pdis-92-10-1421

OPENSHAW, K. A review of Jatropha curcas: an oil plant of unfulfilled promise. Biomass and Bioenergy, v.19, n.1, p.1-15, $2000 . \quad \mathrm{http}: / /$ pdn.sciencedirect.com/science? ob $=$ miamiimageurl\& cid $=271477 \&$ user $=687369 \& \_$pii $=\mathrm{s} 0961953400000192 \& \_$check $=y \&$ origin $=$ browse \& zone $=$ rslt_list_item\&_coverdate $=2000-07-01 \& w c h p=$ dglbvlk-zskwz\&md5= f993cf141b7616fa70fb0988a361f432/1-s2.0-s0961953400000192-main 
PEGG, K.G.; COATES, L.M.; KORSTEN, L.; HARDING, R.M. Foliar, fruit and soil diseases. In: WHILEY, A.W.; SCHAFFER, B.; WOLSTENHOLME, B.N. (Ed.). The avocado: botany, production and uses. Wallingford: CAB International Press, 2002. p.299-338.

PEREIRA, O.L.; DUTRA, D.C.; DIAS, L.A.S. Lasiodiplodia theobromae is the causal agent of a damaging root and collar rot disease on the biofuel plant Jatropha curcas in Brazil. Australasian Plant Disease Notes, v.4, n.1, p.120123, 2009. http://www.publish.csiro.au/?act=view_file\&file_id=dn09049.pdf

PRING, R.J.; NASH, C.; ZAKARIA, M.; BAILEY, J.A. Infection processes and host range of Colletotrichum capsici. Physiological and Molecular Plant Pathology, v.46, n.2, p.137-152, 1995. http://www.dfid.gov.uk/r4d/ output/12324/default.aspx

PRUSKY, D. Pathogen quiescence in postharvest disease. Annual Review of Phytopathology, v.34, p.413-434, 1996. http://www.annualreviews.org/doi/ pdf/10.1146/annurev.phyto.34.1.413

PRUSKY, D.; KEEN, N.T. Involvement of preformed antifungal compounds in the resistance of subtropical fruits to fungal decay. Plant Disease, v.77, n.1, p.114-117, 1993. http://www.apsnet.org/publications/plantdisease/ backissues/documents/1993articles/plantdisease77n02_114.pdf

RAJ, S.K.; SNEHI, S.K.; KUMAR, S.; KHAN, M.S.; PATHRE, U. First molecular identification of a begomovirus in India that is closely related to Cassava mosaic virus and causes mosaic and stunting of Jatropha curcas L. Australasian Plant Disease Notes, v.3, p.69-72, 2008. http://www. springerlink.com/content/u76424vwh6411050/fulltext.pdf
REUVENI, M.; TUZUNS, S.; COLE, J.S.; SIEGEL, M.R.; KUÉ, J. The effects of plant age position on the susceptibility of tobacco to blue mold caused by Peronospora tabacina. Phytopathology, v.76, n.4, p.455-458, 1986. http://www apsnet.org/publications/phytopathology/backissues/documents/1986articles/ phyto76n04_455.pdf

SÁ, D.A.C.; SANTOS, G.R.; FURTADO, G.Q.; LEMUS, E.A.; NASCIMENTO, I.R. Transporte, patogenicidade e transmissibilidade de fungos associados às sementes de pinhão manso. Revista Brasileira de Sementes, v.33, n.4, p.663-670, 2011. http://www.scielo.br/pdf/rbs/v33n4/08.pdf

SANTOS, G.R.; CASTRO NETO, M.D.; RAMOS, L.N.; CAFÉ-FILHO, A.C.; REIS, A.; MOMENTÉ, V.G., PELÚZIO, J.M.; IGNÁCIO, M. Reaction of melon genotypes to the gummy stem blight and the downy mildew. Horticultura Brasileira, v.27, n.2, p.160-165, 2009. http://www.scielo.br/ $\mathrm{pdf} / \mathrm{hb} / \mathrm{v} 27 \mathrm{n} 2 / \mathrm{v} 27 \mathrm{n} 2 \mathrm{a} 07 . \mathrm{pdf}$

SMITH, B.; BLACK, L.L.; GALLETTA, G.J. Resistance to Colletotrichum fragariae strawberry affected by seedling age and inoculated method. Plant Disease, v.74, n.12, p.1016-1021, 1990. http://www.apsnet.org/publications/ plantdisease/backissues/documents/1990articles/plantdisease74n12 1016.pdf

SUTTON, B.C. The genus Glomerella and its anamorph Colletotrichum. In Bailey, J.A.; \& Jeger, M.J. (Eds.) Colletotrichum - Biology, Pathology and Control. Wallingford: CAB International, 1992. p.1-26.

TANAKA, M.A.S.; PASSOS, F.A.; ITO, M.F. Influência da cultivar e do estádio fenológico do fruto de morangueiro sob o desenvolvimento de lesões causadas por Colletotrichum spp. Summa Phytopathologica, v.20, n.3, p.160-163, 1994. 